This item was submitted to Loughborough's Research Repository by the author.

Items in Figshare are protected by copyright, with all rights reserved, unless otherwise indicated.

\title{
Cultural democracy and cultural policy
}

PLEASE CITE THE PUBLISHED VERSION

https://doi.org/10.1080/09548963.2018.1474009

PUBLISHER

(c) Taylor \& Francis

VERSION

AM (Accepted Manuscript)

PUBLISHER STATEMENT

This is an Accepted Manuscript of an article published by Taylor \& Francis in Cultural Trends on 11th June 2018, available online: https://doi.org/10.1080/09548963.2018.1474009

\section{LICENCE}

CC BY-NC-ND 4.0

\section{REPOSITORY RECORD}

Hadley, Steven, and Ele Belfiore. 2019. "Cultural Democracy and Cultural Policy". figshare. https://hdl.handle.net/2134/34178. 


\section{Cultural Democracy and Cultural Policy}

You're asking me, how can people live without some sense that there's an ultimate truth or ultimate scale of values, and I don't know but I don't any longer think that this is just a transitional phase, that we're moving on to some other more settled period. You know I think we're culturally in a phase of permanent revolution - Stuart Hall, speaking on the BBC in the late 1980s.

It is the vanity of every age to consider itself in crisis. Moreover, it is emblematic of both the history of UK cultural policy - and more directly the psychodynamics of the subsidised arts - for this mode of crisis to be both perpetual and endlessly new. Cultural policies need not serve democratic purposes. Nonetheless, within the context of the cultural policy of a twenty-first century liberal democratic state, it is reasonable to expect certain elements or considerations to be pre-requisite. As Hanquinet $(2014$, p.2) argues, "...in all speculation as to the value of culture, there is one aspect which is frequently mentioned but rarely investigated. That is the link between culture and democracy" and yet, "the idea of people's entitlement, or right, to culture is no longer an obvious determinant of cultural policy" (Davies and Selwood, 2012, p.202).

The defining crisis of UK cultural policy has resulted from attempts to combine, articulate and actualise ideas associated with both democracy and culture. Issues of, definitions for and projects to address access, participation, engagement and inclusion abound. In this context, debate around the stratification of cultural consumption resulting from the Warwick Commission's report into cultural value (Neelands et al, 2015) and analysis of Taking Part data from DCMS (Taylor, 2016), alongside more recent work on social mobility in the cultural industries (Brook, O'Brien and Taylor, 2018) has run concurrently with a renewed interest in the ideas and practices of cultural democracy and their potential to address longstanding issues of cultural policy (Wilson, Gross and Bull, 2017). If the arguments about cultural democracy still resonate (Kelly, 2016), then it is perhaps the result of a generational turn of the policy wheel rubbing against an underpinning ideological problematic within the Keynesian model of cultural subsidy. Having previously been considered a remnant of cultural policy history (Kawashima, 2006), 'cultural democracy' has recently acquired new capital via a range of publications, events and research activity operating in, and around, the nomenclature.

The publication of Culture, Democracy and the Right to Make Art: The British Community Arts Movement (Jeffers and Moriarty, 2017) and a subsequent symposium at the University of Manchester in April 2018 facilitated an inter-generational and inter-disciplinary debate on the topic of cultural democracy, bringing together academics, practitioners and students working in the cultural field across multiple decades. Jeffers and Moriarty's work presents a range of first-person narratives and provides a comprehensive, if at times idealistic, account of the Community Arts movement. As Jeffers (2017, p.60) notes, whilst the inaugural Campaign for Cultural Democracy may have stalled following the production and mixed reception of Kelly et al's (1986) Culture and Democracy. The Manifesto, the ideas of cultural democracy "continued to play a vital, if often unrecognized, role in thinking about the relationship between art and people".

As if to prove this point, in November 2018, the Social Theory, Politics and the Arts conference will address the theme of 'Culture, Democracy, and the Arts: Rights Here, Right Now'. Within the call, an interrogation of structural barriers to democratic cultural representation sits alongside recognition of the need to both learn from, and re-contextualise, the work of earlier cultural democracy proponents. There is recognition within the call both to address the contemporary relevance of 
cultural democracy to cultural policy today and to learn from historical understandings of proponents of cultural democracy.

Ideas of participatory democracy are evident in the work of the Movement for Cultural Democracy (a coalition of organisations, groups and individuals seeking cultural democracy in the UK). An overtly political campaign with roots in the now defunct pressure group Arts for Labour, the Movement for Cultural Democracy formed after The World Transformed festival in Brighton in September 2017 and has since launched the draft Manifesto for Cultural Democracy (Movement for Cultural Democracy, 2018). The manifesto calls for - amongst other things - the establishment of a new National Arts Fund (funded by an art market transaction tax) and a new public publishing house, alongside a recognition and re-prioritising of values designed to address the intersectional nature of power systems afflicting the cultural sector above and beyond the embedded hierarchies of class and race within arts policy (Oakley et al, 2018) emanating from Arts Council England.

Within the institution of Arts Council England (ACE), recognition of the need to support and invest in a range of activity that served the popular appetite for creative expression did however pre-date the Warwick Commission's report. ACE's From Indifference to Enthusiasm: Patterns of arts attendance in England (2008, p.8) noted that,

...even if we successfully reduce or remove these barriers, there will still be some people who choose not to engage in the types of arts activities that typically receive public funding. The Arts Council must therefore also consider whether there are opportunities to support arts activities of a different nature, that are relevant to the lives of more people (our emphasis).

Interestingly, this report, like that of the Warwick Commission, used Taking Part data to comment on the social stratification of participation in ACE-funded activity, and came up with an even smaller percentage for the highly engaged with $4 \%$ of the population described as 'voracious' (breakdown into types of arts consumer, England 2005/6).

The scale of activity taking place nationally is evidenced by the recent Kings College London report, Towards cultural democracy: Promoting cultural capabilities for everyone (Wilson, Gross and Bull, 2017). The report is one of the outputs from a large-scale collaborative research project responding to the work of the Get Creative campaign and other national initiatives seeking to enable cultural opportunities in new ways. The report proposes a considered, if not wholly original, approach to understanding cultural democracy as the condition of cultural capability for all. The report is notable for its lack of engagement with the history of cultural democracy and its origin in attempts to challenge established hierarchies of cultural authority and power, which may explain the report's questionably de-politicised approach to the topic (Hadley, 2018).

Dyer (2016) identifies the Arts Council's positioning as an advocate for everyday creativity being evidenced by the report Everyday Creativity (64 Million Artists, 2016) and, more importantly, by its flagship programme, Creative People and Places (CPP). In 2010/11, ACE for the first time had access to local place level data (Active People ${ }^{\mathrm{ii}}$ ). Alongside work being conducted by ACE with the Calouste Gulbenkian Foundation into participatory decision making, the inequalities in engagement patterns revealed by the Active People data led to the development of the Creative People and Places project as an attempt to rebalance the profile of cultural engagement nationally. CPP prioritised the $20 \%$ of places that had the lowest levels of arts engagement according to the Active People data set (average for years 2010 and 2011).

Launched in 2012, Creative People and Places began as an action research programme situated in twenty-one areas across England, aimed at increasing arts engagement by bringing artists, local 
people and other partners together to enable more people to choose, create and take part in arts experiences where they live. ACE initially invested $\mathrm{f} 37 \mathrm{~m}$ iii of National Lottery funding into twentyone independent consortia working within a common framework. It has since allocated a further $\mathrm{f} 15 \mathrm{~m}$ over three further rounds of funds for existing places. A further $£ 37 \mathrm{~m}^{\mathrm{iv}}$ has been committed for the period 2018 to 2022 . This is intended to support existing places to apply for a further 4 years of funding and to support new places to join the programme. In $2016,91 \%^{v}$ of audiences were from lower or medium engaged groups, higher than the average of those groups in the general population.

The extent to which Creative People and Places (in total or part) could be considered a manifestation of cultural democracy is debatable. Nonetheless, the evolving lexicon of CPP and its aligned reportage and activities charts the formation of an attempted shift towards a seemingly culturally democratic discourse from the arts marketing schematic of 'cold spots' (Gilmore, 2013) to everyday creativity (64 Million Artists, 2016) and, potentially, cultural democracy. Unavoidably, such a trajectory for ACE, as the key institution in the subsidised field, is not unproblematic. Tensions between the democratisation of culture and cultural democracy can be traced back to the World War Two work of ACE's forebear, the Council for the Encouragement of Music and the Arts (Belfiore, forthcoming; Jeffers, 2017).

Considered something of a trahison des clercs by Roy Shaw (former Secretary General of the Arts Council of Great Britain) and those of a certain intellectual disposition (see Shaw, 1987), the postwar history of cultural democracy is neither unproblematic nor uncontested. A small number of publications (see Braden, 1978; Kelly, 1984; Dickson, 1995) are testament to the complex ideological, political and social themes of the historical debate. From a cultural policy perspective, this imagined betrayal of artistic standards by writers, academics and practitioners within the Community Arts movement also had a distinctly anti-institutional and political agenda. The demand for cultural democracy, "is a revolutionary demand" (Kelly, 1984, p. 133). Community artists aspired to change the nature of democracy in capitalist societies such that the struggle for cultural democracy was part of a broader attempt at democratisation across all aspects of political, economic and institutional life (Bennett, 2017). Ideas on the role of cultural production in political and social change evidenced the overtly political nature of cultural democracy which saw demands for economic democracy, industrial democracy and political democracy as a corollary of cultural democracy (Kelly, Lock and Merkel, 1986; Kelly, 1984). Even Shaw (1987) acknowledged that the constant crisis in the arts could only be properly addressed with radical changes in economic, social and educational policies.

A key focus of Kelly's work was a critique of cultural authority, particularly as regards the right to say what was, and was not, art. More specific was Kelly's (1985) attack on the idea of the 'Great Tradition of European Art' as being a hegemonic practice which "takes the taste of one (bourgeois) group of people and presents them as the natural taste of civilised people everywhere" (Kelly, 1985, p.3). The blindness of allegiance to the hierarchy of cultural value implicit in the democratisation of culture was not, for Kelly, a simple matter of social origins or a lack of social mobility for, "There are many paths to an unquestioning adherence to 'a scale of values', which is neither justified nor conceived as of needing justification, and undoubtedly some of these paths start at chip shops" (Kelly, 1985, p.4). Kelly (1985) argued not for an extension of the concept of 'the arts' to encompass more activities from more people in more places, but rather its replacement. This radical, political project called for "many localised scales of values, arising from within communities and applied by those communities to activities they individually or collectively undertake" (Kelly, 1985, p.6). In this sense, the impact of cultural democracy on cultural policy becomes an issue that is less of cultural valuation and more one of cultural animation and (self) representation. 
It is now thirty-three years since the AGM of the Shelton Trust for community arts voted to inaugurate a campaign for cultural democracy. Contemporary articulations of, and engagements with, the ideas of cultural democracy must both reconcile themselves with the nuanced and semidocumented history of cultural democracy and the significant macro-level shifts in economic, technological and social fields which have made an imperative of the need to reassess these arguments. For example, if one of the main ambitions of the cultural democracy movement in the 1980s was the decentralisation of the means of cultural production, the (at least theoretical) achievement of this by technological advances calls for a reassessment of the ideas of cultural democracy. The challenge for cultural policy remains avoidance of, "throwing out the precious arts baby with the social bath water" (Shaw, 1985, p.26). The idea, for example, that CPP might act as a counter-balance to the ongoing project of the democratisation of (high) culture could be said to offer little substantive difference to a form of cultural apartheid (Shaw, 1985).

Yet neither the work of the Warwick Commission (Neelands et al, 2015), nor the underlying data provided by Taking Part (Taylor, 2016) signal the failure of the democratisation of culture, nor the failure of the idea per se. They point rather to the failure of a mode of implementation which has variously resulted in a resource-draining physical infrastructure, vested interest (Jancovich, 2015), the rise of managerialism and econometrics and a disposition toward hyperinstrumentalism (Hadley and Gray, 2017). The question then arises as to both if and how cultural policy scholars, arts managers and practitioners should find ways to act upon both the historical base and the potential futures of cultural democracy. Historical research may provide the foundation for the development of a theory of cultural democracy in relation to the issues of cultural authority and normative allocation of cultural value. This would require the theoretical development of a renewed concept of cultural democracy that acknowledges and addresses the social, cultural and economic changes that have taken place since its first formulation in the 1970s. An historically informed yet present- and future-oriented theoretical elaboration of cultural democracy for $21^{\text {st }}$ century British culture and society would need to revise, regenerate and re-fashion a conceptual understanding of what 'cultural democracy' might mean and look like in the present historical moment. A politics of recognition sensitive to issues of class would be the necessary accompaniment to a politics of distribution in struggles for equality and fairness. There can be no true exploration of cultural democracy without the acknowledgement that hierarchies of cultural value have always been, and always will be, imbricated in questions of power and authority: any future research agenda that disregards this connection will fail to make a contribution to both scholarship and to the encouragement of reflexive creative practice.

\section{Notes on Contributors}

\section{Steven Hadley}

Dr Steven Hadley is a Visiting Research Fellow (School of Performance \& Cultural Industries, University of Leeds) and Research Associate (School of Music, University of Sheffield). An internationally recognised expert on audience development, Steven is Policy and Reviews Editor for Cultural Trends and an Associate Consultant with The Audience Agency. Current research focuses on the relationship of arts management to ideology and cultural policymaking at a national level. Recent publications include work on hyperinstrumentalism in cultural policy, the strategic development of cultural organisations and cultural democracy. His forthcoming book, 'Audience Development and Cultural Policy' is published by Palgrave MacMillan.

\section{Eleonora Belfiore}


Eleonora Belfiore is Professor of Communication and Media Studies at Loughborough University, UK. She has published extensively on cultural politics and policy, and particularly the place that notions of the 'social impacts' of the arts have had in British cultural policy discourses. For Palgrave she has published, with Oliver Bennett, The Social Impact of the Arts: An intellectual history (2008) and coedited with Anna Upchurch a volume entitled Humanities in the Twenty-First Century: Beyond Utility and Markets (2013). More recently, her research has focused on researching the politics of cultural value, and she was Director of Studies of the Warwick Commission on the Future of Cultural Value (2013-5), and co-author of its final report, Enriching Britain: Culture, creativity and growth, published in February 2015. Eleonora is co-investigator on the AHRC funded Connected Communities project 'Understanding Everyday Participation - Articulating Cultural Values' and research lead in the Paul Hamlyn-funded 3-year Fun Palaces Ambassador Programme. For Palgrave, she edits the book series New Directions in Cultural Policy Research.

Orcid

Steven Hadley http://orcid.org/0000-0003-2240-7808

\section{References}

64 Million Artists (2016). Everyday Creativity. Retrieved from http://64millionartists.com/everydaycreativity-2/

Arts Council England (ACE) (2008). From Indifference to Enthusiasm: Patterns of arts attendance in England. Accessed from

http://webarchive.nationalarchives.gov.uk/20160204122823/http://www.artscouncil.org.uk/adviceand-guidance/browse-advice-and-guidance/from-indifference-to-enthusiasm-patterns-of-artsattendance-in-england

Arts Council England (ACE) (2018) The Active Lives Survey. Accessed from https://www.artscouncil.org.uk/participating-and-attending/active-lives-survey

Belfiore, E. (forthcoming). Policy discourse, cultural value and the 'problem of participation'. In E. Belfiore \& L. Gibson (Eds.) Culture and Power: Histories of participation, values and governance. London: Palgrave.

Bennett, O. (2017) Memories, Dreams, Reflections: Community Arts as Cultural Policy - the 1970s. In A. Jeffers \& G. Moriarty (Eds.), Culture, democracy and the right to make Art (pp.161-181). London: Bloomsbury Methuen Drama.

Braden, S. (1978). Artists and people. London: Routledge \& Kegan Paul PLC.

Brook, O., O'Brien, D. and Taylor, M. (2018). Panic! Social Class, Taste and Inequalities in the Creative Industries. Accessed from http://createlondon.org/event/panic-paper/

Davies, M. and Selwood, S. (2012) In Search of Cultural Policy, Cultural Trends, Vol.21, No.3 pp.201204.

Dickson, M. (ed.)(1995). Art with People. Sunderland: AN Publications.

Dyer, L. (2016). The value of everyday creativity. London: Arts Council England. Accessed from http://www.artscouncil.org.uk/blog/value-everyday-creativity 
Gilmore, A. (2013) Cold spots, crap towns and cultural deserts: The role of place and geography in cultural participation and creative place-making, Cultural Trends, 22:2, 86-96.

Hadley, S. (2018). Towards cultural democracy: promoting cultural capabilities for everyone, Cultural Trends, 27:1, 52-55.

Hadley, S. and Gray, C. (2017). Hyperinstrumentalism and cultural policy: means to an end or an end to meaning?, Cultural Trends

Hanquinet, L. (2014) Cultural Practices and democratic issues: an exploration, Paper presented at the Public Forum on Culture and Democracy held as part of the 13th Assembly of Council of Europe/ERICarts experts, Compendium of Cultural Policies and Trends in Europe.

Jancovich, L. (2015) The participation myth, International Journal of Cultural Policy pp.1-15.

Jeffers, A. (2017). The community arts movement 1968-1986. In A. Jeffers \& G. Moriarty (Eds.), Culture, democracy and the right to make Art (pp. 35-64). London: Bloomsbury Methuen Drama.

Jeffers, A., \& Moriarty, G. (2017). Culture, democracy and the right to make Art. London: Bloomsbury Methuen Drama.

Kawashima (2006) AUDIENCE DEVELOPMENT AND SOCIAL INCLUSION IN BRITAIN, International Journal of Cultural Policy, 12:1, 55-72.

Kelly, O. (1984). Community, Art and the state: Storming the citadels. London: Comedia.

Kelly, O. (1985). In Search of Cultural Democracy. Arts Express, October.

Kelly, O. (2016). Community, art and the state: Storming the citadels (2nd ed.). Dib Dib Dob. This is available online only from:

https://www.academia.edu/470872/Community_art_and_the_state_Storming_the_citadels

Kelly, O., Lock, J., \& Merkel, K. (1986). Culture and Democracy. The Manifesto. London: Comedia.

Movement for Cultural Democracy (2018). Manifesto for Cultural Democracy. Accessed from http://culturaldemocracy.uk/

Neelands, J., Belfiore, E., Firth, C., Hart, N., Perrin, L., Brock, S., \& Woddis, J. (2015). Enriching Britain: Culture, creativity and growth. Coventry: University of Warwick.

Oakley, K., Ball, M. and Cunningham, M. (2018). Everyday Culture and the Good Life. CUSP Working Paper No.9. Retrieved from https://www.cusp.ac.uk/wp-content/uploads/WP09-Everyday-Cultureand-the-good-life.pdf

Shaw. R. (1985) Can a million flowers bloom? Arts Express, Aug-Sept pp.25-27.

Shaw, R. (1987). The Arts and the People. London: Jonathan Cape.

Taylor, M. (2016). Nonparticipation or different styles of participation? Alternative interpretations from Taking Part. Cultural Trends 25(3), 169-181. 
The Audience Agency (2017) Creative People and Places Profiling and Mapping 2014-2016 National Report. Retrieved from

http://www.creativepeopleplaces.org.uk/sites/default/files/Audience\%20Agency\%20profiling\%2020 14-2016\%20-\%20national\%20report.pdf

Wilson, N., Gross, J., \& Bull, A. (2017). Towards cultural democracy: Promoting cultural capabilities for everyone. Retrieved from https://www.kcl.ac.uk/Cultural/-/Projects/Towards-culturaldemocracy.aspx

\footnotetext{
' Members include Red Pepper Magazine, Public and Commercial Services Union Culture Group, the Raymond Williams Foundation, Culture Matters, The World Transformed, Sophie Hope, Ashish Ghadiali, Hassan Mahamdallie, Rose Gibbs and Stephen Pritchard.

ii The Active Lives Survey explores participation in leisure and recreational activities, including sport, physical activity and culture. The survey is led by Sport England in partnership with the Arts Council, Public Health England and Department for Transport.

iii This included $f 1 \mathrm{~m}$ for the peer learning network and the evaluation programme.

iv This includes approx. 750k for evaluation and peer learning.

${ }^{\vee}$ The Audience Agency (2017).
} 